\title{
Analysis of The Patient Queue System at The Puskesmas Lubuk Begalung
}

\author{
$1^{\text {st }}$ Siti Aisyah \\ Mathematics Department \\ State University of Padang \\ Padang, Indonesia \\ siti02.aisyah1295@gmail.com
}

\begin{abstract}
Long queues at a service facility result in a buildup of customer numbers, so service time increases. This condition is often found in public service facilities such as services at the puskesmas, one of which is the Lubuk Begalung Health Center. The results showed that the queue model at the Lubuk Begalung Health Center was less effective. So that it needs additional employees, especially on Monday, Tuesday and Wednesday.
\end{abstract}

\section{Keywords- The Queue, Effectivity, Accidental Sampling}

\section{INTRODUCTION}

A line of people or goods waiting to be served is called a queue [1]. Queues are activities that often occur in everyday life such as queuing at banks, queuing at supermarket cashiers, queuing at hospitals and others. Queues occur when people who need services exceed the capacity of the service or inadequate service facilities. Service facility users who arrive cannot immediately obtain services. This is due to the busy service which results in long queues. Long queues at a service facility result in accumulation of customer numbers, so service time is getting longer. This condition is often found in public service facilities such as services at the puskesmas, one of which is the Lubuk Begalung Health Center.

Lubuk Begalung Health Center is a health center located on Jalan Pulai Air. District of Lubuk Begalung. Lubuk Begalung Health Center is included in the type of health center for non-hospitalization. Based on observations on February 5, 2018 at the Lubuk Begalung Health Center, patients seeking treatment at this puskesmas were divided into two, namely using BPJS and non BPJS cards. Patients who use BPJS cards are more than patients who use non BPJS cards. The Lubuk Begalung Health Center has nine treatment centers (BP), namely, general medical clinics, dental treatment centers, elderly medical centers, child centers, maternity treatment centers, nutrition treatment centers, immunizations, TB treatment centers (Tuberculosis), and family planning (Family Planning). ) The treatment center whose patients are mostly in general treatment centers.

The increase in the number of patients at the Lubuk Begalung Health Center occurred since the enactment of this type of payment using BPJS cards. The community whose BPJS card has been registered with the Lubuk Begalung Health Center cannot do the treatment at other puskesmas. However, if the patient wants to do the treatment at a public hospital then he must get a referral letter from the Lubuk

\author{
$2^{\text {nd }}$ Helma \\ Mathematics Department \\ State University of Padang \\ Padang, Indonesia \\ helma667@yahoo.co.id
}

Begalung Health Center except in an emergency. This causes patients who seek treatment during peak hours to queue long, especially when waiting to get status on the registration section.

Based on the results of the observation on February 5 , 2018 , the duration of the patient's status was due to a large number of heaps of files in the registration section and in the search for the status of the patient still using the manual method. This can be seen in the average time waiting for patients in the system for Monday, Tuesday and Wednesday that is 103 minutes/person, while for Thursday is 50 minutes/person, for Friday 100 minutes/person, and for Saturday is 79 minutes/person. According to one patient who treated at the Lubuk Begalung Health Center a long waiting time for treatment made the patient feel sicker and finally, someone decided not to seek treatment.

As a result of these problems, research was conducted to analyze the queuing system at the Lubuk Begalung Public Health Center, which in turn could obtain an optimal queuing system. One way to overcome this problem is the need for a balance between waiting time for patients and unemployment.

The optimal queuing system is seen from the point of view of fulfilling certain aspirations set by decision makers. The level of aspiration in this study is the target to be achieved by the puskesmas with the aim of improving services. This level of aspiration is determined as the upper limit of conflicting measure values, which decision makers want to balance. The level of aspiration [2] is that the average time to wait in the system is no more than 10 minutes, while the unemployment time is not more than $20 \%$.

In this study, researchers need supporting theories to complete the final project, such as the basic elements of the queuing system. This section discusses customer arrival patterns, queuing systems, service levels, and customer arrivals. Another theory needed is the queue process. This queue process discusses four queue structures, namely one single-stage channel, many single-stage channels, one multistage channel, and many multi-stage channels.

\section{METHOD AND RESEARCH}

\section{A. Type of Research}

This research is applied research with theoretical analysis followed by data retrieval. This applied research is a research that applies a problem in everyday life to mathematics. 


\section{B. Population and Samples}

The population is an expansion area consisting of objects or subjects that have special qualities and characteristics set by the researcher so that researchers can study and then draw conclusions [3]. Samples are objects that are taken to be studied and are expected to represent the entire population [4]. The sampling technique used was accidental sampling. Accidental sampling is a sampling which is based on a coincidence, where coincidentally meeting with the researcher can be used as a sample if viewed as someone who happens to be found suitable as a data source [5].

The study population was all patients treated at the Lubuk Begalung Health Center and the sample of the study were patients who were in the registration section and patients who were treated at the general treatment center at the Lubuk Begalung Health Center.

\section{Types and Data Sources}

The data used in this study is secondary data. In this secondary data, the researcher takes the queue data directly at the Lubuk Begalung Health Center, which is the average data of patients waiting in the queue, the average patient waiting in the system, the average time in the system. , and the average time in the queue.

\section{Data Collection Techniques}

Data collection techniques used are the direct observation in the registration section and BP general Lubuk Begalung Health Center. The observation was carried out to obtain data when the patient arrived, the time the patient began to be served and the time the patient was finished being served. At the time of data collection, the author was assisted by a friend, where the tool used in this study was a digital clock.

\section{E. Data Analysis Techniques}

1. Calculate the average interarrival time $(1 / \lambda)$, calculate the average service time $(1 / \mu)$

2. Conduct Kolmogorov-Smirnov test on time data between patient arrival and patient service time for six days.

3. Calculate the number of patients who come time union $(\lambda)$

4. Calculating the number of patients who finished serving time union $(\mu)$, and Calculating the value of $\rho / \mathrm{c}$

5. Calculate the average number of patients in the system $\left(L_{s}\right)$, using the formula:

$$
L_{s}=f(b)\left(\frac{\lambda}{c \mu-\lambda}\right)+\frac{\lambda}{\mu}
$$

6. Calculate the average number of patients in the queue $\left(L_{q}\right)$, using the formula:

$$
L_{q}=f(b)\left(\frac{\lambda}{c \mu-\lambda}\right)
$$

7. Calculate the average time of patients in the system $\left(w_{s}\right)$, using the formula:

$$
w_{s}=f(b)\left(\frac{1}{c \mu-\lambda}\right)+\frac{1}{\mu}
$$

8. Calculates the average time a patient waits in the queue $\left(w_{q}\right)$ using the formula:

$$
w_{q}=f(b)\left(\frac{1}{c \mu-\lambda}\right)
$$

9. Make decisions with aspiration levels

\section{RESULT AND DISCUSSION}

\section{A. Result of Analysis}

The average time between the arrivals of patients on Monday is 4.7 minutes/person. Data between patient arrival times for Monday has an exponential distribution because of the Asymp.Sig (2-tailed) value is above 0.05. Furthermore, the average service time for Monday is 44.8 minutes/person. Service time data for Monday is exponentially distributed because of the Asymp.Sig (2-tailed) value is above 0.05. The average time between the arrivals of patients on Tuesday 5 minutes/person.

Time data between patient arrivals for Tuesday exponential distribution because of the value of Asymp. Sig (2-tailed) is above 0.05. Furthermore, the average service time for Tuesday is 55 minutes/person. Service time data for Tuesday has an exponential distribution because of the Asymp. Sig (2-tailed) value is above 0.05 . The average time between the arrivals of patients on Wednesday was 4.85 minutes/person.

The time between patient arrivals for Wednesday is an exponential distribution because of the Asymp.Sig (2-tailed) value is above 0.05 . Furthermore, the average service time for Wednesday is 54 minutes/person. The service time data for Wednesday has an exponential distribution because of the Asymp. Sig (2-tailed) value is above 0.05. The average time between the arrivals of patients on Thursday was 3.82 minutes/person.

The inter-patient arrival time data for Thursday has an exponential distribution because of the Asymp.Sig (2-tailed) value is above 0.05 . Furthermore, the average service time for Thursday is 40 minutes/person. Data on service time for Thursday has an exponential distribution because of the Asymp.Sig (2-tailed) value above 0.05. The average time between the arrivals of patients on Friday is 7.5 minutes/person.

The time between patient arrivals for Friday is exponentially distributed because of the Asymp.Sig (2tailed) value is above 0.05 . Furthermore, the average service time for Friday is 52.7 minutes/person. Data the service time for Friday is exponentially distributed because of the Asymp.Sig (2-tailed) value is above 0.05 . The average time between the arrivals of patients on Saturday was 3.93 minutes/person.

The inter-patient arrival time data for Saturday has an exponential distribution because of the Asymp.Sig (2-tailed) value is above 0.05 . Furthermore, the average service time for Saturday is 36.2 minutes/person. Data The service time for Saturday has an exponential distribution because of the Asymp.Sig (2-tailed) value is above 0.05 . The results of the exponential distribution test for inter-arrival time data can be seen in Table 1. 
TABLE 1

INTER-ARRIVAL TIME DISTRIBUTION TEST

\begin{tabular}{|l|l|l|l|}
\hline Day & $\begin{array}{l}\text { Exponential } \\
\text { Parameters } \\
(\mathrm{a}, \mathrm{b})\end{array}$ & $\mathrm{N}$ & $\begin{array}{l}\text { Asymp.sig.(2- } \\
\text { tailed) }\end{array}$ \\
\hline $\begin{array}{l}\text { Monday/5 } \\
\text { February } 18\end{array}$ & 13,43 & 7 & 0,914 \\
\hline $\begin{array}{l}\text { Tuesday/6 } \\
\text { February } 18\end{array}$ & 10,57 & 7 & 0,954 \\
\hline $\begin{array}{l}\text { Wednesday/7 } \\
\text { February 18 }\end{array}$ & 13,67 & 7 & 0,068 \\
\hline $\begin{array}{l}\text { thursday/8 } \\
\text { February } 18\end{array}$ & 9,67 & 6 & 0,998 \\
\hline $\begin{array}{l}\text { Friday/9 } \\
\text { February } 18\end{array}$ & 6,67 & 7 & 0,274 \\
\hline $\begin{array}{l}\text { Saturday/10 } \\
\text { February } 18\end{array}$ & 8,29 & 7 & 0,491 \\
\hline
\end{tabular}

The results of the exponential distribution test for service time data can be seen in table 2 .

$$
\text { TABLE } 2
$$

SERVICE Distribution Test Time

\begin{tabular}{|l|l|l|l|}
\hline Day & $\begin{array}{l}\text { Exponential } \\
\text { Parameters } \\
(\mathrm{a}, \mathrm{b})\end{array}$ & $\mathrm{N}$ & $\begin{array}{l}\text { Asymp.sig } \\
\text {.(2-tailed) }\end{array}$ \\
\hline $\begin{array}{l}\text { Monday/5 } \\
\text { February } 18\end{array}$ & 8,00 & 6 & 0,311 \\
\hline $\begin{array}{l}\text { Tuesday/6 } \\
\text { February } 18\end{array}$ & 5,43 & 7 & 0,985 \\
\hline $\begin{array}{l}\text { Wednesday/7 } \\
\text { February 18 }\end{array}$ & 7,00 & 6 & 0,460 \\
\hline $\begin{array}{l}\text { thursday/8 } \\
\text { February } 18\end{array}$ & 10,00 & 7 & 0,519 \\
\hline $\begin{array}{l}\text { Friday/9 } \\
\text { February } 18\end{array}$ & 7,00 & 6 & 0,852 \\
\hline $\begin{array}{l}\text { Saturday/10 } \\
\text { February } 18\end{array}$ & 10,00 & 6 & 0,576 \\
\hline
\end{tabular}

\section{A. Discussion}

Based on the results of data analysis, for the data of inter-arrival time and patient service time in the registration section and BP for six days, the Asymp.Sig (2-tailed) $>\alpha$ value was obtained, the inter-arrival time data and patient service time in the registration section were exponentially distributed. Monday, Tuesday, Wednesday, Thursday, Friday and Saturday with 8 employees, the terms $\lambda /$ (c $\mu)<1$ are not met, so the number employees must be added by considering the percentage of employee unemployment and the average time to wait for patients in the system. On Monday if there are additional employees to 14 people, the percentage of unemployed is $7 \%$ of the working time and the average time to wait for patients in the system is 103 minutes. If the employee is added to 15 people the percentage of unemployed employees' increases to $13 \%$ of his working time and the average time to wait for patients in the system to decrease to 75 minutes. If employees are added to 16 people the percentage of unemployed employees' increases to $19 \%$ of their working time and the average time to wait for patients in the system to decrease to 67 minutes. The data can be seen in Table 3 .
TABLE 3

BASIC SIZES OF Queue THEORY C AMOUNT OF EMPLOYEES FOR MONDAY

\begin{tabular}{|l|c|c|c|}
\hline \multicolumn{1}{|c|}{$\begin{array}{c}\text { Basic measures of } \\
\text { queuing theory }\end{array}$} & $\mathbf{c = 1 4}$ & $\mathbf{c = 1 5}$ & $\mathbf{c = 1 6}$ \\
\hline $\begin{array}{l}\text { The average number in } \\
\text { the system }\end{array}$ & 23 & 17 & 15 \\
\hline $\begin{array}{l}\text { The average number in } \\
\text { the queue }\end{array}$ & 10 & 4 & 2 \\
\hline $\begin{array}{l}\text { Average time in the } \\
\text { system }\end{array}$ & 103 & 75 & 67 \\
\hline $\begin{array}{l}\text { Average time in the } \\
\text { queue }\end{array}$ & 73 & 15 & 7 \\
\hline $\begin{array}{l}\text { Percentage of } \\
\text { unemployed employees }\end{array}$ & $13 \%$ & $19 \%$ \\
\hline
\end{tabular}

On Tuesday if there are additional employees to 13 people, the percentage of unemployed employees is $8 \%$ of the working time and the average time to wait for patients in the system is 103 minutes. If the employee is added to 14 people the percentage of unemployed employees' increases to $14 \%$ of his working time and the average time to wait for patients in the system to decrease to 75 minutes. If the employee is added to 15 people the percentage of unemployed employees' increases to $20 \%$ of his working time and the average time to wait for patients in the system to decrease to 67 minutes. The data can be seen in Table 4 .

$$
\text { TABLE } 4
$$

BASIC SIZES OF QUEUE THEORY C AMOUNT OF EMPLOYEES FOR TODAY

\begin{tabular}{|l|l|l|l|}
\hline $\begin{array}{l}\text { Basic measures of } \\
\text { queuing theory }\end{array}$ & $\mathbf{c = 1 3}$ & $\mathbf{c = 1 4}$ & $\mathbf{c = 1 5}$ \\
\hline $\begin{array}{l}\text { The average number in } \\
\text { the system }\end{array}$ & 21 & 15 & 14 \\
\hline $\begin{array}{l}\text { The average number in } \\
\text { the queue }\end{array}$ & 9 & 3 & 2 \\
\hline $\begin{array}{l}\text { Average time in the } \\
\text { system }\end{array}$ & 103 & 75 & 67 \\
\hline $\begin{array}{l}\text { Average time in the queue } \\
\text { Percentage of } \\
\text { unemployed employees }\end{array}$ & 83 & 15 & 7 \\
\hline
\end{tabular}

On Wednesday if there are additional employees to 14 people, the percentage of unemployed employees is $7 \%$ of the working time and the average time to wait for patients in the system is 103 minutes. If the employee is added to 15 people the percentage of unemployed employees' increases to $13 \%$ of his working time and the average time to wait for patients in the system to decrease to 75 minutes. If employees are added to 16 people the percentage of unemployed employees increased to $19 \%$ of their working 
time and the average time to wait for patients in the system decreased to 67 minutes. The data can be seen in Table 5 .

TABLE 5

BASIC SIZES OF QUEUE THEORY C AMOUNT OF EMPLOYEES FOR WEDDING

\begin{tabular}{|l|l|l|l|}
\hline $\begin{array}{l}\text { Basic measures of } \\
\text { queuing theory }\end{array}$ & $\mathbf{c = 1 4}$ & $\mathbf{c = 1 5}$ & $\mathbf{c = 1 6}$ \\
\hline $\begin{array}{l}\text { The average number in } \\
\text { the system }\end{array}$ & 23 & 17 & 15 \\
\hline $\begin{array}{l}\text { The average number in } \\
\text { the queue }\end{array}$ & 10 & 4 & 2 \\
\hline $\begin{array}{l}\text { Average time in the } \\
\text { system }\end{array}$ & 103 & 75 & 67 \\
\hline $\begin{array}{l}\text { Average time in the } \\
\text { queue }\end{array}$ & 43 & 15 & 7 \\
\hline $\begin{array}{l}\text { Percentage of } \\
\text { unemployed employees }\end{array}$ & $7 \%$ & $13 \%$ & $19 \%$ \\
\hline
\end{tabular}

On Thursday, if there are additional employees to 9 people, the percentage of unemployed employees is $11 \%$ of the working time and the average time to wait for patients in the system is 50 minutes. If the employee is added to 10 people the percentage of unemployed employees increases to $20 \%$ of his working time and the average time to wait for patients in the system to decrease to 37 minutes. If employees are added to 11 people the percentage of unemployed employees' increases to $27 \%$ of their working time and the average time to wait for patients in the system to decrease to 33 minutes. The data can be seen in Table 6 . TABLE 6

BASIC SIZES OF QUEUE THEORY C AMOUNT OF EMPLOYEES FOR THURSDAY

\begin{tabular}{|l|l|l|l|}
\hline $\begin{array}{l}\text { Basic measures of queuing } \\
\text { theory }\end{array}$ & $\mathbf{c = 9}$ & $\mathbf{c = 1 0}$ & $\mathbf{c = 1 1}$ \\
\hline $\begin{array}{l}\text { The average number in the } \\
\text { system }\end{array}$ & 14 & 10 & 9 \\
\hline $\begin{array}{l}\text { The average number in the } \\
\text { queue }\end{array}$ & 6 & 2 & 1 \\
\hline Average time in the system & 50 & 37 & 33 \\
\hline Average time in the queue & 19,6 & 6,14 & 2,45 \\
\hline $\begin{array}{l}\text { Percentage of unemployed } \\
\text { employees }\end{array}$ & $11 \%$ & $20 \%$ & $27 \%$ \\
\hline
\end{tabular}

On Friday, if there are 9 additional employees, the percentage of unemployed employees is $11 \%$ of the working time and the average time to wait for patients in the system is 99 minutes. If the employee is added to 10 people the percentage of unemployed employees' increases to $20 \%$ of his working time and the average time to wait for patients in the system to decrease to 72 minutes. If the employee is added to 11 people the percentage of unemployed employees' increases to $27 \%$ of his working time and the average time to wait for patients in the system to decrease to 65 minutes. The data can be seen in Table 7 .

TABLE 7

BASIC Sizes of QueUe THEORY C AMOUNT OF EMPLOYEeS FOR FRIDAY

\begin{tabular}{|l|l|l|l|}
\hline $\begin{array}{l}\text { Basic measures of queuing } \\
\text { theory }\end{array}$ & $\mathbf{c = 9}$ & $\mathbf{c = 1 0}$ & $\mathbf{c = 1 1}$ \\
\hline $\begin{array}{l}\text { The average number in the } \\
\text { system }\end{array}$ & 14 & 10 & 9 \\
\hline $\begin{array}{l}\text { The average number in the } \\
\text { queue }\end{array}$ & 6 & 2 & 1 \\
\hline Average time in the system & 99 & 72 & 65 \\
\hline Average time in the queue & 39,2 & 12,28 & 4,9 \\
\hline $\begin{array}{l}\text { Percentage of unemployed } \\
\text { employees }\end{array}$ & $11 \%$ & $20 \%$ & $27 \%$ \\
\hline
\end{tabular}

On Saturday, if there are 8 additional employees, the percentage of unemployed employees is $6 \%$ of the working time and the average waiting time for patients in the system is 78 minutes. If the employee is added to 9 people the percentage of unemployed employees' increases to $17 \%$ of his working time and the average time to wait for patients in the system to decrease to 40 minutes. If the employee is added to 10 people the percentage of unemployed employees' increases to $25 \%$ of his working time and the average time to wait for patients in the system to decrease to 34 minutes. The data can be seen in Table 8 .

$$
\text { TABLE } 8
$$

BASIC Sizes of Queue THEORY C AMOUNT OF EMPLOYEeS For SATURDAY

\begin{tabular}{|l|l|l|l|}
\hline $\begin{array}{l}\text { Basic measures of } \\
\text { queuing theory }\end{array}$ & $\mathbf{c = 8}$ & $\mathbf{c = 9}$ & $\mathbf{c = 1 0}$ \\
\hline $\begin{array}{l}\text { The average number in } \\
\text { the system }\end{array}$ & 20 & 11 & 9 \\
\hline $\begin{array}{l}\text { The average number in } \\
\text { the queue }\end{array}$ & 13 & 3 & 1 \\
\hline $\begin{array}{l}\text { Average time in the } \\
\text { system }\end{array}$ & 78 & 40 & 34 \\
\hline $\begin{array}{l}\text { Average time in the } \\
\text { queue }\end{array}$ & 48,44 & 10,18 & 3,68 \\
\hline $\begin{array}{l}\text { Percentage of } \\
\text { unemployed employees }\end{array}$ & $6 \%$ & $17 \%$ & $25 \%$ \\
\hline
\end{tabular}

The optimal system in the registration and general treatment (BP) section, can be determined using aspiration levels. The use of aspiration levels, where the unemployment time is no more than $20 \%$ of the working time, and the average time to wait for patients in the system is no more than 10 minutes. Based on the results of data processing it 
turns out that for all unemployed employees all days meet the predetermined numbers of $6 \%, 7 \%, 8 \%$, and $11 \%$, while the average time waiting for patients in the system does not meet the predetermined numbers. So that the percentage of unemployed employees is $11 \%$ of their working time with the average time waiting for patients in the system for 49.6 minutes. This is due to the fact that for services from the registration section until before the patient is examined by a doctor in the BP section, the service can be expedited, but the doctor's service cannot be accelerated because the patient needs to be examined properly, so the patient must wait until the patient is previously served. So, in order for the queue system to run effectively, additional employees are needed, especially on Monday, Tuesday and Wednesday.

\section{CONCLUSION}

The queue system in the registration and treatment center (BP) section has not been effective with the number of employees of eight people. The queuing system that has not been effective has been caused because the patient's waiting time in obtaining patient status requires quite a long time. So that it is necessary to add staff in the search for patient status. Employee addition can be done with employees who work part time, because the addition of employees is only needed on Monday, Tuesday, Wednesday and Thursday.

The level of aspiration used is the average time waiting in the system for Monday, Tuesday, Wednesday and Thursday 68 minutes/person, while for Thursday and Friday 38 minutes/person. The percentage of unemployed employees is $20 \%$.

\section{REFERENCES}

[1] J. Heizer, and Render, Barry. Manajemen Operasi. Jakarta: Salemba Empat. 2006

[2] Asmirawati, Devi. Model Antrian M/M/C dan Penerapannya pada Bank Negara Indonesia Padang. Padang: UNP. 2004

[3] Sugiyono. Metode Penelitian Administrasi. Bandung: Alfabeta . 2005

[4] S. Notoatmojo. Metodologi Penelitian Kesehatan. Jakarta: Rineka Cipta. 2003

[5] H. Usman, dan Purnomo Setiady Akbar. Pengantar Statistika . Jakarta: Bumi Aksata. 1995 